\title{
Nilai-Nilai Keislaman dan Keindonesiaan dalam Membentuk Karakteristik Peradaban Melayu di Indonesia (Studi Pemikiran Munawir Sjadzali)
}

\author{
Toharudin \\ Program Pascasarjana \\ Universitas Islam Negeri Raden Fatah Palembang \\ Email: toharudinrizal@gmail.com
}

\begin{abstract}
Abstrak
Penelitian ini merupakan penelitian kepustakaan, yakni manuskrip karya Munawir Sjadzali tentang Islam dan Pancasila. Manuskrip ini menyatakan bahwa Islam dan Pancasila di Indonesia masih menjadi persoalan yang belum selesai. Sikap umat Islam Indonesia terbagi ke dalam tiga golongan. Golongan integralistik (Islam sebagai dasar negara secara formal), golongan nasionalis (menolak pandangan integralistik), dan golongan modernis menganggap tidak ada pertentangan antara Islam dan Pancasila sehingga Pancasila dapat diterima sebagai dasar negara bangsa Indonesia yang mayoritas muslim. Munawir Sjadzali adalah modernis muslim yang menegaskan bahwa Islam dan Pancasila merupakan dua hal saling berkaitan, dengan Pancasila umat Islam dapat membangun sebuah peradaban Islam yang universal secara legal di Indonesia. Penelitian ini menghasilkan temuan bahwa: Pertama, Islam menurut Munawir Sjadzali adalah sebuah sistem kehidupan yang menurut penganutnya untuk aktif mewujudkan dalam kehidupan umat Islam di dunia nyata. Termasuk dalam kehidupan berbangsa dan bernegara sebagai sumber inspirasi dan motivasi, landasan etika dan moral dalam membangun peradaban di Indonesia. Kedua, strategi yang ditawarkan Munawir Sjadzali dalam membangun peradaban di Indonesia yaitu dengan mereaktualisasikan nilai keislaman dan keindonesiaan, yaitu nilai berketuhanan, nilai kemanusiaan yang adil dan beradab, nilai persatuan dan kesatuan, nilai kebijaksanaan dalam kepemimpinan, dan nilai keadilan. Kelima nilai tersebut dikenal dengan mana Pancasila. Ketiga, Pancasila yang secara subtantif adalah nilai-nilai ajaran Islam, umat Islam Indonesia membangun ilmu baru, sistem dan tatanan kemasyarakatan baru yang tertata secara Islami itulah bangsa Indonesia membangun sebuah peradaban Islam tanpa nama Islam secara formal, serta dapat bersaing dan mengungguli peradaban dunia lainnya, secara cerdas dan bermartabat.
\end{abstract}

Kata Kunci: Pemikiran, Munawir Sjadzali, Peradaban, Implementasi, Ajaran Islam

Islam merupakan agama yang sejak awal kehadirannya telah bersentuhan dengan permasalahan kedaulatan secara luas. Bahkan sejarah awal Islam telah dipenuhi dengan kisah kejayaan sistem pemerintahan dan strategi militer Nabi Muhammad SAW [1]. Dalam gambaran keseluruhan sejarahnya, Islam adalah venture atau usaha yang tidak kenal berhenti untuk mewujudkan masyarakat yang dicita-citakan dan venture itu melibatkan orang-orang muslim dalam praktek semua bidang kegiatan hidup, dengan sendirinya termasuk dalam hal ini adalah peradaban [2]. Karena hal itulah umumnya para sajarawan muslim menyimpulkan bahwa Nabi Muhammad SAW bukan saja membawa ajaran agama Islam tetapi juga membawa sebuah tatanan peradaban baru [3].

Dengan demikian pemikiran peradaban Islam adalah aktifitas dan proses yang telah mengalami perjalanan sejarah yang sangat panjang dan belum pernah berhenti sampai hari ini. Selain disebabkan oleh hal-hal yang telah disebutkan di atas, hal ini juga dikarenakan Islam telah membuat sejarah selama lebih dari 14 abad, sehingga merupakan 


\section{Toharudin}

Nilai-Nilai Keislaman dan Keindonesiaan dalam Membentuk Karakteristik Peradaban Melayu di Indonesia (Studi Pemikiran Munawir Sjadzali)

suatu kenaifan jika dianggap dalam sejarah panjang itu segala sesuatu bersifat tetap. Dalam perjalanan sejarahnya tersebut Islam memiliki pembendaharaan pengalaman maupun teori mengenai peradaban yang sangat kaya dan luas. Hal ini menempatkan pembahasan mengenai peradaban Islam sebagai sesuatu yang terus berkembang [1].

Siti Maryam menjelaskan, bahwasannya dalam perjalanan dan perkembangan peradaban Islam mengalamai pasang surut yang dapat dibagi ke dalam tiga periode: Periode awal peradaban Islam di Timur Tegah pada abad 7-13 M. Periode penyebaran peradaban Islam Timur Tengah ke wilayah lain pada abad 13-19 M. Periode perkembangan modern umat Islam abad 19-20 M [4]. Ketiga periode ini terbagi ke dalam tiga fase: Fase pertama, berlangsung antara akhir abad ke- 18 sampi awal abad ke-20. Dalam fase ini elite politik bangsa, agama dan kekuasaan masyarakat muslim berusaha menetapkan pendekatan keagamaan dan ideologi baru bagi perkembangan masyarakat mereka.

Fase kedua, berlangsung setelah perang Dunia I sampai pertengahan abad ke- 20. Dalam fase ini kalangan elite negara-negara muslim membawa identitas peradaban modern terhadap masyarakat mereka dan berusaha memprakarsai pengembangan ekonomi serta perubahan sosial. Fase ketiga, berlangsung sekitar pasca perang Dunia II. Fase ini ditandai dengan pertentangan antara kecendrungan terhadap perkembangan yang tengah berlangsung dengan peran utama Islam itu sendiri.

Secara khusus, periode ketiga serta ketiga fasenya memiliki karakteristik yang sangat berbeda dengan periode sebelumnya karena periode ketiga ini sangat dipengaruhi oleh tiga faktor besar yaitu (1). Kemunduran peradaban dunia Islam, (2). Kolonialisme yang terjadi di kawasan Islam berhadapan dengan (3). Keunggulan Barat. Tiga faktor ini kemudian memberikan dampak sangat besar pada lahirnya peradaban Islam modern kontemporer yang sangat beragam secara mendasar [5]. Dampak tersebut berpengaruh kepada intelektual Islam modern kontemporer di seluruh dunia Islam termasuk di Indonesia.

Kepulauan Nusantara yang mayoritas penduduknya beragama Islam juga mengalami periode pasang surut perkembangan peradaban Islam. Diawali dengan berdirinya kesultanan-kesultanan Islam di seluruh Nusantara, kemudian masuknya penjajahan bangsa Eropa yang berdampak pada hancurnya kesultanan-kesultanan tersebut, dilanjutkan dengan dominasi penjajahan Belanda baik secara ekonomi, politik, hukum, budaya, kemasyarakatan, bahkan agama yang selanjutnya memicu perlawanan serta perjuangan kemerdekaan yang menyatukan masyarakat di bagian-bagaian wilayah kesultanan Islam dan memproklamasikan berdirinya suatu negara Republik yaitu Negara Kesatuan Republik Indonesia.

Bangsa Indonesia yang memproklamasikan kemerdekaan pada tanggal 17 Agustus 1945 yang pada dasarnya penduduk bangsa Indonesia mayoritas beragama Islam dengan wilayah yang meliputi seluruh kesultanan-kesultanan Islam di kepulauan Nusantara, namun pada saat kemerdekaan bersepakat untuk mendirikan negara nasional yaitu Negara Kesatuan Republik Indonesia (NKRI), hal ini tercantum dalam pasal 1 ayat 1 UU 1945 berbunyi bahwa "negara Indonesia ialah negara kesatuan, yang berbentuk republik". 
Negara kesatuan adalah bentuk yang ditetapkan sejak awal berdirinya negara Indonesia dan dipandang paling tepat untuk mewadahi ide persatuan sebuah bangsa yang majemuk ditinjau dari berbagai latar belakang bangsa Indonesia sendiri.

Pada akhirnya memilih Pancasila sebagai dasar negara, tertulis dalam pasal $36 \mathrm{~A}$ yaitu "lambang negara ialah Garuda Pancasila dengan semboyan Bhinneka Tunggal Ika" [6]. Pilihan tersebut telah menimbulkan dampak dalam perkembangan politik Islam di Indonesia dari sejak awal kemerdekaan hingga saat ini. Baik dampak yang berupa mempersoalkan Islam dan Pancasila sebagai dasar negara maupun juga dampak berupa akomodasi yaitu usaha-usaha untuk mengangkat titik temu antara Islam dan Pancasila.

Pertentangan dalam pembahasan mengenai hubungan Islam dan negara terjadi sejak tahun 1920 an. Saat itu terjadi polemik yang sangat tajam mengenai hubungan Islam dan dasar negara, mengenai nasionalisme juga mengenai ideologi antara Muhammad Natsir yang mewakili kelompok Islamisme dengan Soekarno yang mewakili kelompok nasionalisme [7]. Kemudian pertentangan itu berlanjut dalam sidang BPUPKI (Badan Penyelidik Usaha Persipan Kemerdekaan Indonesia) pada saat berlangsungnya pembahasan mengenai persoalan dasar negara, kemudian berlanjut mengerucut menjadi pertentangan antara dua pihak yaitu kelompok Islamisme dan kelompok nasionalisme. Kelompok Islam berusaha memperjuangkan Islam agar dapat memiliki kedudukan legal formal secara langsung sebagai dasar negara. Berseberangan dengan itu, kelompok nasionalis menolak hubungan agama dan negara yang bersifat legalistik dan formalistik sebagaimana yang dituntut kelompok Islam [5].

Mohammad Natsir sebagai tokoh yang mewakili kelompok Islam dalam salah satu pidatonya menegaskan pandangannya mengenai Pancasila bahwa:

Kalaupun ada sila Ketuhanan Yang Maha Esa dalam Pancasila, itu sebenarnya adalah la diniyah, tanpa agama dan tidak bersumber pada wahyu Ilahi. Ia hanya merupakan penggalian di masyarakat. Ketuhanan dalam Pancasila hanyalah rasa adanya Tuhan tanpa wahyu. Karena itu, rasa Ketuhanan tersebut bersifat relatif, berganti-ganti [8]. Bila umat Islam berpindah dari Islam ke Pancasila berarti mereka melompat dari bumi tempat berpijak ke ruang hampa [9].

Dalam pidato Mohammad Natsir di atas, dapat dicermati bahwa Sila Ketuhanan Yang Maha Esa merupakan peralihan dari ketiadaan Tuhan yang sesungguhnya, yang dapat dijadikan sebagai pintu dalam pendirian suatu peradaban. Ketuhanan Yang Maha Esa adalah wujud dari hilangnya rasa ketauhidan dalam diri manusia, artinya manusia adalah dalam kegamangan jiwa dan raga.

Sebaliknya Soekarno mewakili kelompok nasional mengemukakan bahwa agama adalah urusan spiritual perseorangan, ataupun bersifat individual yang pada dasarnya berada pada jiwa dan raga setiap warga negara dalam suatu negara itu. dengan demikian maka pelaksanaan ajaran-ajaran agama hendaknya menjadi tanggung jawab individual kaum muslim. Negara tidak memiliki wewenang untuk turut campur atau untuk mengatur apalagi memaksa ajaran-ajaran agama apapun kepada warga negaranya atau yang dinyatakan dengan agama negara. Dengan demikian, tanggung jawab maju ataupun 


\section{Toharudin}

Nilai-Nilai Keislaman dan Keindonesiaan dalam Membentuk Karakteristik Peradaban Melayu di Indonesia (Studi Pemikiran Munawir Sjadzali)

keterbelakangan agama Islam sepenuhnya berada di pundak pribadi-pribadi muslim itu sendiri [7].

Mengenai hubungan agama dan negara Soekarno mengemukakan bahwa tidak terdapat dalam Al-Qur'an dan tidak terdapat pula dalam ijma' ulama mengenai keharusan tentang bersatunya agama dan negara. Di samping itu Nabi Muhammad SAW diutus untuk membawa ajaran moral keagamaan dan penyempurnaan ajaran-ajaran yang telah ada sebelumnya, sedangkan negara adalah urusan keduniaan dengan demikian negara Islam itu tidak ada. Dalam dunia Islam yang terjadi pada masa Nabi Muhammad SAW masih hidup ialah berdirinya negara Islam berupa Kota Madinah, yang didalamnya terdapat berbagai umat beragama, namun tidak dipaksakan untuk mematuhi syariatsyariat dalam ajaran Islam secara Formal. Menurut Soekarno kalaupun ada hal itu datang jauh sesudah Nabi Muhammad SAW wafat [7].

Uraian di atas menggambarkan bahwa Muhammad Natsir dan Soekarno mempunyai pendapat yang bertolak belakang mengenai hubungan Islam dan negara. Namun di samping dua pendapat tersebut terdapat pula pendapat ketiga yang bercorak akomodatif [10] ditandai dengan sikap fleksibel yang bisa memberikan segala kebijakan rezim terutama yang berkaitan dengan persoalan hubungan agama dan negara yang melahirkan pola simbiotik atau hubungan saling memberi dan menerima antara agama dan negara.

Pendapat ketiga ini, tidak seperti kelompok Islamisme yang memutlakkan penyatuan agama dan negara secara formal sebagai dasar negara, juga tidak seperti pandangan kelompok nasional yang memutlakkan pemisahan antara agama dan negara, dalam pandangan pola simbiotik, agama dan negara berada dalam posisi seimbang dan hubungan timbal balik saling memerlukan. Agama memerlukan negara agar dapat berkembang dan mendapat legitimasi, sedangkan negara memerlukan agama agar mendapatkan bimbingan etika, moral, dan spiritual [5]. Tokoh-tokoh yang berpandangan simbiotik meyakini bahwa meskipun agama Islam tidak menjadi agama negara secara formal namun Islam dapat memberikan sumbangan besar berupa etika dan moral untuk penataan kehidupan bernegara.

Munawir Sjadzali merupakan seorang pemikir pluridisipliner dengan agenda keilmuan mengintegrasikan sains dengan agama dalam sebuah strukturasi pemikiran yang koheren, atau sering diistilahkan dengan misi Islamisasi ilmu pengetahuan. Dalam diri Munawir Sjadzali tergabung pemikiran modern dan jiwa yang tenang (sufisme), Munawir Sjadzali juga aktif dalam kegiatan tarekat Sjadzaliyyah [11]. Ciri yang paling menonjol dari Munawir adalah kemampuannya untuk memahami kitab-kitab klasik Islam. Pada gilirannya, hal ini membawa implikasi pada luasnya wawasan keagamaan, karir intelektual dan pemerintahan, serta kebijakan-kebijakan yang berkaitan dengan jabatannya sebagai Menteri Agama nantinya. Bidang keilmuan yang ditekuninya merentang dari filsafat, ekonomi, hingga ilmu pertanian yang bersifat teknis.

Pemikirannya mengenai Islam mulai dikenal luas setelah Munawir Sjadzali menerbitkan naskah yang berisi pemikirannya mengenai kebangkitan intelektual peradaban Islam [12]. Naskah tersebut dibawakan pada saat Munawir Sjadzali mewakili pemerintah pada Konferensi Kebangkitan Islam di Islamabad Pakistan. 
Dalam misi Islamisasi ilmunya, persoalan mengenai hubungan antara Islam dan dasar negara juga menjadi pembahasan pokok. Dalam karya-karyanya Munawir Sjadzali mendudukkan mengenai Negara Kesatuan Republik Indonesia (NKRI), Pancasila, UUD 1945, dan kaitannya dengan Islam sebagai suatu yang khusus. Hal ini cukup berbeda dengan cendikiawan muslim lainnya yang membahas persoalan mengenai hubungan Islam dan dasar negara sebagai sebuah bahasan umum atau memandang NKRI dan Islam sebagai dua hal berbeda namun dapat saling mengisi dan saling bertergantungan atau pola simbiotik.

Dalam naskah yang berjudul Bunga Rampai Wawasan Islam Dewasa Ini, Munawir Sjadzali mengungkapkan pemikirannya mengenai Islam, NKRI, Pansaila, dan UUD 1945. Munawir Sjadzali memandang bahwa Islam, NKRI, Pancasila, dan UUD 1945 sebagai satu kesatuan. Keempat hal itu merupakan bagian dari perjalanan sejarah Islam yang akan menjadi starting point bagi terbangunnya kembali peradaban Islam untuk kali yang kedua. Munawir Sjadzali berpandangan bahwa Proklamasi kemerdekaan RI adalah bagian dari perjalanan sejarah Islam dan Pancasila serta UUD 1945 adalah bagian dari ajaran Islam karena dirumuskan dari pengalaman dan perjalanan hidup umat Islam Indonesia. Perjuangan kemerdekaan yang menyatukan masyarakat di bagian-bagaian wilayah kesultanan Islam didasari dengan istilah ukhuwah Islamiyah (persatuan sesama umat Islam) dan ukhuwah insaniyah (persatuan sesama umat manusia) juga dibalik kesultanan Islam itu turut andil perjuangan umat non muslim dalam perjuangan kemerdekaan dari penjajahan. Al-Qur'an dalam beberapa ayatnya menjelaskan kepada umatnya untuk selalu menjaga persatuan. Di antaranya adalah tercermin dalam surat Ali Imron ayat 103, yang artinya Artinya:

"Dan berpegang teguhlah kamu sekalian dengan tali Allah dan janganlah kamu sekalian berpecah belah, dan ingatlah nikmat Allah atas kamu semua ketika kamu bermusuh-musuhan maka dia (Allah) menjinakkan antara hati-hati kamu maka kamu menjadi bersaudara sedangkan kamu di atas tepi jurang api neraka, maka Allah mendamaikan antara hati kamu. Demikianlah Allah menjelaskan ayat-ayatnya agar kamu mendapatkan petunjuk"

Dalam buku yang berjudul Islam, Realitas Baru, Dan Orientasi Masa Depan Bangsa. Munawir Sjadzali mengungkapkan pemikiranya mengenai hubungan atara Islam dan dasar negara. Islam terlalu sakral untuk diletakkan kepada sebuah benda untuk dijadikan sekedar sebuah label bagi benda itu. Secara khusus menurut Munawir Sjadzali, Pancasila dan bangsa Indonesia adalah pelopor kebangkitan Islam untuk yang kedua kalinya dan Indonesia akan menjadi pusat peradaban Islam dunia.

Dalam penelitian yang dilakukan oleh Muhammad Panji Ketawang [13] dengan tema “Menjawab Persoalan Bangsa Menuju Masa Depan Cemerlang” temuannya yaitu dalam pandangan Munawir Sjadzali mengenai Islam dan dasar negara dalam hal ini Islam dan Pancasila, berangkat dari keprihatinannya melihat kondisi umat Islam Indonesia yang berada dalam kegamangan sikap (di antara dua), antara ke-Indonesia sebagai bagian dari bangsa Indonesia di satu sisi dan ke-Islaman sebagai seorang muslim. Menurut Munawir Sjadzali kegamangan sikap ini disebabkan oleh persoalan Islam dan Pancasila sebagai 


\section{Toharudin}

Nilai-Nilai Keislaman dan Keindonesiaan dalam Membentuk Karakteristik Peradaban Melayu di Indonesia (Studi Pemikiran Munawir Sjadzali)

dasar negara yang tidak kunjung berakhir sampai saat ini. Islam dan Pancasila masih diposisikan sebagai dua hal yang berdiri sendiri-sendiri. Munawir Sjadzali berpendapat hal ini sebagai kekeliruan dan harus diluruskan. Munawir Sjadzali menyatakan Islam dan Pancasila adalah satu kesatuan.

Secara metodologis penelitian ini merupakan jenis penelitian kualitatif dengan tempat penelitian kepustakaan (library research). Data penelitian ini terdiri dari data primer berupa karya Munawir Sjadzali dan data sekunder yakni data yang berkaitan dengan permasalahan penelitian ini. Data secara komprehensip dikumpulkan menggunakan empat macam teknik yaitu: heuristik, verifikasi, dan interpretasi yaitu analisis (menguraikan) dan sintesis (menyatukan) data, dan historiografi (ditulis dalam bentuk tulisan).

\section{Pemikiran Munawir Sjadzali Mengenai Stategi dalam Membangun Peradaban}

Pada bagian ini peneliti melanjutkan bahasan untuk menjawab permasalahan keempat yaitu pemikiran Munawir Sjadzali mengenai nilai-nilai keislaman dan keindonesiaan untuk membangun karakter peradaban bangsa. Agar pembahasan mengenai karakter bangsa dapat tergambar baik, maka peneliti terlebih dahulu membahas pemikiran Munawir Sjadzali mengenai persoalan-persoalan yang berkaitan langsung dengan permasalahan yaitu mengenai nilai keislaman dan keindonesiaan. Karena itu bagian ini membahas dua persoalan dengan urutan persoalan sebagai berikut:

Islam memahami manusia dalam pendekatan yang konferhensif. Manusia terdiri dari aspek fisik ata jasmani, yang terdiri dari kesehatan, keberhasilan, dan kerapian. Aspek spritual yang berkaitan dengan pengembangan keberagamaan masyarakat yaitu keimanan dan ketakwaan kepada Allah SWT. aspek emosi berkaitan dengan pengembangan aspek afektif umat beragama atau masyarakat umumnya, yaitu peduli, kreatif, dan empati [14]. Aspek intelktual berkatan dengan kecerdasan umat Islam atau masyarakat. Aspek-aspek karakter inilah yang dikembangkan dalam Islam dan menjadi akhlak terpuji yang dapat membangun karakter bangsanya menjadi berperadaban unggul.

Dengan memahami manusia dan perilaku dalam prespektif Islam, maka manusia terdiri dari unsur jasmani, rohani, dan nafsani yang menjadikan manusia sebagai makhluk yang sempurna di muka bumi. Manusia memiliki kebebasan dalam memilih perilaku yang baik atau yang buruk, yang benar atau yang salah, oleh karena itu manusia dibekali oleh Allah SWT akal dan hati [9].

Unsur-unsur yang ada pada manusia membutuhkan tumbuh kembang yang sehat supaya bisa menjalankan fungsi manusia sebagai khalifatul fil ardih dimana dapat menjalankan tugas-tugas kemanusiaan dan peradabannya. Proses tumbuh kembang manusia akan dapat dicapai secara optimal melalui pendidikan yang dapat mengembangkan segala unsur dan potensi yang ada pada dirinya.

Demikian juga dengan gagasan Kuntowijoyo [15] yang menyatakan bahwa manusia dalam Islam digambarkan sebagai makhluk yang merdeka, dan karena hakikat kemerdekaannya itu manusia menduduki tempat yang sangat terhormat (sebagai wakil Allah SWT di muka bumi). Dalam banyak ayat Al-Qur'an diserukan agar manusia 
menemukan esensi dirinya, memikirkan kedudukannya dalam struktur realitas, sehingga mampu menempatkan dirinya sesuai dengan keberadaan kemanusiaanya.

Peneliti berpendapat bahwa, dengan paradigma Islam, yaitu mengajarkan pembebasan, bukan pengekangan seperti agama-agama lain. Aktualisasi diri manusia hanya terwujud dengan sempurna dalam pengabdian kepada penciptanya. Dan ini jelas merupakan pembebasan sejati. Sebagaimana paradigma dapat disimpulkan bahwa Islam memiliki kekuatan untuk menjadi dasar bagi konsepsi tingkah laku, dan sistem gagasan yang diperlukan dalam kehidupan secara menyeluruh. Dengan pengaktualisasi kembali nilai keislaman dan keindonesiaan yang bersinergi positif, maka karakter bangsa yang unggul dapat terbentuk secara efektif.

Pengertian yang tepat mengenai nilai keislaman dan Pancasila Untuk Membangun Karakter Bangsa, Munawir Sjadzali terlebih dahulu memualai pembahasan dengan mengupas persoalan mengenai kontruksi karakter bangsa. Untuk itu pada bagian ini peneliti mengangkat pemikiran Munawir Sajzali mengenai konseptual dengan menggunakan pilar moral. Meliputi aspek otonomi dan heteronomi.

Dalam sebuah dialog yang menarik antara seorang Teologi Barazil yang bernama Leonardo Boff dengan Dalai Lama dalam sebuah diskusi reundtable, [16] "apa yang membuat seseorang menjadi baik ?, jika seseorang menjadi lebih sabar, sesintif, peduli, memiliki rasa kemanusiaan, tanggung jawab, dan beretika, maka agama telah berkerja untuk kamu. Alam raya adalah refleksi dari apa yang manusia pikirkan dan apa yang manusia lakukan. Jika manusia melakukan kebaikan akan menerima kebaikan, jika manusia melakukan kejahatan, akan menerima keburukan".

Dialog ini mengisaratkan betapa agama dapat menjadi amat fungsional dan bekerja dengan baik, ketika agama dapat merefleksi pada perilaku keseharian seseorang menjadi pribadi yang baik. Agama bukan nilai yang terpisah dari kehidupan nyata, tetapi menyatu dalam perilaku manusia.

Pada sisi lain, akhir-akhir ini di Indonesia fenomena sosial sangat menghawatirkan, yang ditandai berbagai degradasi kehidupan etika moral terjadi dalam lingkup yang bervariasi. Doni Kusuma [17], menyebutkan beberapa fenomena, yaitu kebangrutan moral bangsa, maraknya tindak kekerasan, inkoherensi politisi atau retorika politik, dan perilaku keseharian.

Senada dengan Doni Kusuma yang menyatakan kebangkrutan moral bangsa, Munawir Sjadzali [18], mengemukakan bahwa pada sisi lain akhir-akhir ini di Indonesia fenomena sosial mengalami kebangrutan, dari pendekatan moral sosial yang muncul akhir-akhir ini cukup menghawatirkan. Fenomena kekerasan dalam menyelesaikan masalah menjadi hal yang umum. Pemaksaan kebijakan terjadi hampir pada setiap level intitusi. Manipulasi informasi menjadi hal yang lumrah. Penekanan dan pemaksaan kehendak satu kelompok terhadap kelompok lain dianggap biasa. Hukum begitu teliti terhadap kesalahan, tetapi buta pada keadilan.

Sepertinya karakter masyarakat Indonesia yang santun dalam berperilaku, musyawarah mufakat dalam menyelesaikan masalah, wilayah yang kaya dengan pluralitas, toleransi, dan gotong royong, telah berubah wujud menjadi hegemoni 


\section{Toharudin}

Nilai-Nilai Keislaman dan Keindonesiaan dalam Membentuk Karakteristik Peradaban Melayu di Indonesia (Studi Pemikiran Munawir Sjadzali)

kelompok-kelompok baru yang saling mengalahkan [19]. Bahkan dalam sepuluh tahun terakhir kasus kekerasan dan kerusuhan meninggkat tajam. Kasus kekerasan terjadi dalam berbagai dimensi, di antaranya ada yang bermatras politik, bermatras ekonomi, bahkan agama. Kasus kekerasan yang menonjol dalam tahun-tahun terakhir ini di antaranya kakus kekerasan pada anak dan perempuan, kasus kekerasan sosial, serta kasus kekerasan bermatras agama.

Menurut Idzam Fautanu [16] "dalam menyikapi hal-hal belakangan ini munculnya pertanyaan epistimologis, bagaimana nilai-nilai keislaman dan Pancasila dapat mewujud dalam karakter bangsa Indonesia?’. Bangsa Indonesia mempunyai karakter unggul yang akan membangun peradaban unggul. Peradaban dunia dibangun oleh bangsa-bangsa yang memiliki keunggulan bukan hanya dalam bidang sains dan teknologi tetapi yang paling utama adalah bangsa yang penduduknya, masyarakatnya, atau umat manusia yang memiliki karakter mulia, jujur, bertanggung jawab, menjadi warga negara yang baik, kuat, positif mandiri, dan pekerja keras. Bentuk-bentuk karakter tersebut yang akan menjadi sebuah bangsa yang memiliki distingsi dan dihargai pergaulan bangsa-bangsa dunia.

Munawir Sjadzali [18] menjelasakan ketika mayoritas karakter masyarakat kuat, positif, tangguh maka peradaban yang tinggi dapat di bangun dengan baik dan sukses, sebaliknya jika mayoritas karakter masyarakat memiliki karakter negatif dan lemah mengakibatkan peradaban yang dibangunpun menjadi lemah, sebab peradaban tersebut dibangun dalam fondasi yang amat lemah.

Karakter bangsa adalah modal dasar membangun peradaban tinggkat tinggi, masyarakat yang memilki sifat jujur, mandiri, bekerja-sama, patu pada peraturan, bisa dipercaya, tangguh, dan memiliki etos kerja tinggi akan menghasilkan sistem kehidupan sosial yang teratur dan baik. Ketidak teraturan sosial menghasilkan berbagai bentuk tindak kriminal, kekerasan, terorisme, dan lain-lain. Menyikapi karater bangsa Munawir Sjadzali [20] membagi dua aspek moral, yaitu:

Karakter bangsa Indonesia secara konseptual dengan menggunkan pilar moral. Karakter individual maupun komunal dibangun melalui dua aspek yang saling terkait yaitu aspek otonomi dan aspek heteronomi. Otonomi merupakan usaha dalam proses pendidikan yang diimplementasikan melalui pengajaran, pembiasaan, peneladanan, motivasi, dan penegak aturan.

Sementara, aspek heteromoni merupakan usaha yang dilakukan oleh lingkungan (luar pendidikan) yakni adalanya keadilan sosial ekonomi, penegakan hukum tanpa timbang pilih, keteladanan pimpinan, serta keteraturan norma-norma social [21].

Dalam membentuk karakter bangsa dibutuhkan sinergi yang kuat antara aspek otonomi dan aspek heteronomi. Jika salah satunya rapuh atau bahkan saling bertentangan, maka karakter bangsa tidak akan terbentuk secara efektif. Dari aspek-aspek heteronomi yang ditawarkan Munawir Sjadzali, di atas maka penulis akan mencoba menguraikannya: a. Aspek keadilan sosial ekonomi, dengan adanya keadilan sosial dan ekonomi, maka akan membebaskan manusia dari konflik yang berkepanjangan karena terjadinya kesenjangan dan ketidak adilan dalam menikmati hasil-hasil pembangunan. Ada 
sebagaian kecil jumlah orang yang bisa menikmati sebagian besar kemakmuran ditengah sebagian besar jumlah orang yang hanya bisa menikmati sebagian kecil kemakmuran. Disinilah potensi konflik yang amat laten, yang kalau tidak bisa diselesaikan akan merusak tatanan kehidupan berbangsa dan bernegara.

b. Aspek penegakan hukum, hukum bersifat direktif langsung mengarahkan prilaku orang, nama yang harus dan tidak harus dilakukan dalam konteks kepentingan sosial kemasyarakatan. Dalam hukum ada konsekuensi-konsekuensi yang harus ditanggung oleh masing-masing orang, sehingga dengan adanya penegakan hukum, orang akan tau batas-batas tentang hak dan kewajiban masing-masing berkaitan dengan kepentingan dirinya dan orang lain.

c. Aspek keteladanan pimpinan bangsa, akan menjadi simpul penting terbentuknya karakter suatu bangsa. jika pemimpinnya taat aturan, konsisten, dan bersahaja maka pimpinan tersebut akan menjadi role model dan panutan bagi yang dipimpinnya. Karakter-karakter baik dan mulia pemimpinya akan menjadi contoh nyata bentuk karakter yang diinginkan. Sementara itu, bangsa yang memiliki karakter kuat akan menjadi bangsa yang bisa memimpin peradaban dunia.

d. Aspek keteraturan norma-norma sosial, keteraturan sosial dapat menjamin semua kepentingan, baik individu maupun kelompok. Kepentingan-kepentingan tersebut dapat terpenuhi secara wajar tanpa adanya konflik dengan pihak lain. Oleh karena itu, interaksi sosial bagi seorang anak sangat penting dalam membentuk karakter sosial yang baik dan mampu menghasilkan calon-calon warganegara yang baik.

Dalam bagan tersebut tergambar bahwa, tanpa adanya aspek-aspek tersebut maka kontruksi karakter bangsa tidak akan terwujud secara efektif, kalau terjadinya kesenjangan sosial ekonomi yang semakin melebar, lemahnya penegakan hukum, tidak adanya keteladanan pemimpin serta kekacauan norma-norma sosial yang semakin menjadi. Peneliti berpendapat bahwa, adapun nilai-nilai keindonesiaan atau Panacasila itu ialah nilai-nilai luhur universal dan kosmopolitan bangsa Indonesia. Nilai-nilai ini tentu harus didasarkan pada agama atau budaya hasil dialog panjang dengan agama (Islam). Nilai-nilai ini mempunyai peranan yang strategis sekaligus sentral dalam membangun persatuan umat. Persatuan ini menumbuhkan kemantapan diri sendiri sebagai bangsa. Oleh karenanya pertumbuhan kemantapan itu berjalan sejajar dengan pertumbuhan nilai-nilai keindonesiaan atau Pancasila itu sendiri.

Menurut peneliti kemantapan itu berimplikasi kepada kebebasan diri dari rasa takut terhadap pluralitas maupun rasa cemas kepada arus globalisme atau pengaruh asing. Sehingga kemantapan nilai-nilai keindonesiaan atau Pancasila menjadi pangkal adanya fase pertumbuhan lebih lanjut yang lebih penting, yaitu pase keterbukaan atau dalam istilah kontemporernya ialah inklusivitas.

Inklusivitas [22] dalam kehidupan beragama adalah salah satu aspek yang paling penting dalam warga negara, masyarakat suatu bangsa yang plural. Untuk itu Nurcholish Madjid (Cek Nur) mengatakan bahwa "Indonesia dalah salah satu bangsa yang paling plural di dunia", atau dengan kata lain bahwa penduduk Indonesia adalah paling beranekaragam agama dan kulturnya di muka bumi. 


\section{Toharudin}

Nilai-Nilai Keislaman dan Keindonesiaan dalam Membentuk Karakteristik Peradaban Melayu di Indonesia (Studi Pemikiran Munawir Sjadzali)

Munawir Sjadzali, menyatakan dengan demikian dapat diatarik suatu kesimpulan bahwa "keindonesiaan atau Pancasila" bangsa Indonesia sangat beragama, meskipun realitasnya dalam keberagaman tersebut mayoritas beragama Islam. Islam masuk ke Indonesia dengan cara damai [23]. Untuk itu, modal keindonesiaan yang paling berharga ialah persatuan, keutuhan wilayah negara, bahasa kesatuan, kontitusi dan falsafah negara. Sistem pemeintahan yang meliputi seluruh tanah air dan pembangunan ekonomi secara pragmatis.

Menurut peneliti senada dengan unkapan Munawir Sjadzali bahwa selain modal keindonesiaan yang paling mahal adalah pengalaman bangsa Indonesa menjalani kehidupan masyarakat yang pluralis. Sehingga modal tersebut, yaitu keindonesiaan, menunjukkan adanya kecendrungan umum ke arah terwujudnya konvergensi nasional yaitu suatu bentuk saling pengertian yang berakar dalam semangat untuk memberi dan menerima. Sikap ini bermuara pada kemantapan masing-masing kelompok, golongan, dan agama serta hilangnya kekhawatiran antar mereka.

Atas dasar kemajemukan atau pluralisme internal masyarakat Indonesia dan kecendrungan ke arah konvergensi nasional yang mantap, maka pengembangan peradaban Islam di Indonesia memerlukan pemahaman dan strategis yang tepat [24]. Dari sini kemudian memunculkan pemikiran wawasan keindonesiaan. Munawir Sjadzali [25] menegaskan bahwa wawasan keindonesiaan adalah pemahaman dan pengetahuan tentang lingkungan sosial kultural masyarakat Indonesia secara keseluruhan. Karena itu harus diperhitungkan bahwa Indonesia merupakan suatu negara bangsa yang mempunyai keanekaragaman yang tinggi secara fisik, yaitu negara kepulauan, keragaman suku, bahasa, adat istiadat, dan agama. Melihat kenyataan ini maka setiap langkah melaksanakan ajaran Islam di Indonesia harus memperhitungkan kondisi sosial budaya untuk menuju ke kemajuan [26].

Dari paparan Munawir Sjadzali di atas, maka penulis memahami bahwa bangsa Indonesia menuju ke arah negara bangsa yang berarti menuju Indonesia yang demokratis, egaliter, dan adil. Indonesia merupakan negara dengan penduduk yang beranekaragam dan dengan budaya yang bermacam-macam pula. Namun budaya yang bermacam-macam ini ada yang bisa mendukung terwujudnya negara bangsa yang sejalan dengan cita-cita negara tersebut.

Dalam hal ini peneliti berpendapat bahwa, yang paling penting untuk dilakukan adalah, budaya yang beranekaragam itu harus mewujud ke arah keindonesiaan. Dalam perjalanan sejarah kebangsaan, proses pertumbuhan keindonesiaan tidak terbatas pada satu tempat dan dalam satu masa. Sebagaimana sering diungkapkan oleh para pemimpin bangsa bahawa keindonesiaan mempunyai akar-akar yang jauh dalam sejarah Nusantara.

\section{Pemikiran Munawir Sjadzali dalam Membangun Karakter Peradaban Berbasis Islam dan Keindonesiaan}

Pada akhir 1990, Munawir Sjadzali mempersembahkan kepada masyarakat sebuah buku dengan judul Islam dan Tata Negara; Ajaran, Sejarah, dan Pemikiran. Buku tersebut semula ditulisnya sebagai buku panduan bagi mahasiswa S3 yang mengambil 
mata kuliah al-Fiqh al-Siyasi. Dengan sikap rendah hati dan kejujuran diakuinya bahwa pemikiran yang ditulisnya itu merupakan hasil akhir sementara dari suatu pengembaraan intelektual yang cukup panjang dan penjelajahan ilmiah yang lumayan luasnya yang terdorong oleh obsesi untuk dapat menjawab tentang ada atau tidak adanya teori atau konsep politik atau ketatanegaraan dalam Islam.

Pendekatan yang ditempuh Munawir Sjadzali agak berbeda dengan ilmuwan lain dan menunjukkan sikap intelektual muslim yang langka ditemukan di masyarakat kita dewasa ini. Munawir Sjadzali menyatakan:

"Tanpa dibebani misi untuk membuktikan sesuatu, serta sama sekali tanpa praduga dan prakonsepsi, saya masuk ke khazanah kepustakaan Islam termasuk karyakarya klasik, dengan kepala terbuka mengkaji apa pun yang saya jumpai dan mempunyai kaitan dengan pencarian saya itu, dengan menjunjung tinggi kejujuran tentang dan terhadap Islam, dan menaati kaidah-kaidah keilmuwan dan objektivitas intelektual."

"Kemudian pada akhir kajian nanti akan saya susun hasil-hasil penggalian saya itu, dan akan saya katakan: Inilah Islam sejauh yang saya temukan sampai hari ini. Kalau misalnya di kemudian hari saya menemukan fakta-fakta baru yang tidak senapas dengan apa yang selama ini saya miliki, tetapi mempunyai dasar ilmiah yang cukup kuat untuk diperhatikan, maka demi Islam dan demi ilmu, saya tidak akan segan-segan meninjau kembali apa yang selama ini saya yakini. Itulah sebabnya mengapa di muka tadi saya menyatakan bahwa buku Islam dan Tata Negara itu merupakan hasil akhir sementara. Artinya, sementara sampai saya menemukan fakta-fakta baru yang lebih menguatkan isi buku itu atau sebaliknya yang berbeda dari hasil pencarian saya selama ini." [20]

Tidak semua orang sependapat dengan kesimpulan penelitiannya itu. Seorang ilmuwan dan tokoh politik Islam ketika itu setelah membaca tesisnya, menyatakan penyesalannya bahwa Munawir Sjadzali menulis tesis itu atas dasar ilmu untuk ilmu dan kurang memperhatikan tuntutan perjuangan Islam [27]. Hal yang sangat mengesankan pada Munawir Sjadzali ialah ungkapan yang sering disitirnya dalam berbagai tulisan dan pemikirannya, "Sebagai seorang muslim saya ingin mengikuti tradisi keilmuwan Imam Abu Hanifah. Merupakan suatu kebiasaan yang sangat terpuji bahwa beliau selalu menutup fatwa dengan ucapan: Apa yang baru saja saya katakan itu (hanyalah) suatu pendapat, dan inilah yang terbaik yang dapat saya berikan. Kalau kemudian ada orang (lain) yang datang dan memberikan pendapat yang lebih baik dari pendapat saya ini, maka (pendapat) dialah yang lebih tepat untuk dianggap sebagai yang benar daripada (pendapat) saya."

Gerakan Islam yang memperjuangkan formalisasi Syariat Islam dalam Institusi negara atau pemerintah merupakan arus baru dalam perkembangan Islam mutakhir di Indonesia karena menampilkan Islam serba syariat dengan orientasi yang formalistik ideologis. Gerakan ini berbeda dengan gerakan Islam politik lama yang diwakili oleh gerakan kultural seperti NU, Muhammadiyah, maupun kelompok intelektual baru, dengan coraknya yang inklusif-subtantif. Kelompok Islam politik masa reformasi ditandai dengan munculnya kelompok-kelompok Tarbiyah, Hizbutahrir Indonesia, FPI, Majlis Mujahidin dan lainnya [27]. 


\section{Toharudin}

Nilai-Nilai Keislaman dan Keindonesiaan dalam Membentuk Karakteristik Peradaban Melayu di Indonesia (Studi Pemikiran Munawir Sjadzali)

Secara umum, Islam politik Pasca Orde Baru, dapat dikategorikan ke dalam dua kelompok besar yaitu kelompok yang bertipe struktural dan kelompok yang bertipe kultural. Kelompok pertama, diwakili oleh partai-partai politik Islam, baik yang secara eksplisit merupakan partai Islam PBB, PKS, PKNU, PPP dan yang lainnya. Serta partaipartai yang basis masanya lebih dominan berbasiskan masyarakat muslim seperti PAN, dan PKB. Kelompok kedua, diwakili oleh Fron Pembela Islam, Forum Komunikasi Ahlu Sunnah Wal Jamaah atau biasa dikenal sebagai Laskar Jihad, MMI, HAMMAS, Ikwanul Muslim maupun Hizbutahrir. Kelompok ini di tengarai berhaluan puritan, berkarakter militan, radikal, skriptualis, konserpatif dan ekslusif. Meski memiliki platform berbeda, tapi mereka memiliki satu visi yaitu pembentukan negara Islam (daulah Islamiyah) dan formalisasi syariat Islam merupakan muara dari semua aktifitas mereka.

Menarik untuk dicatat, bahwa belakangan ini bermunculan peraturan daerah di beberapa daerah yang bernuansa syariah. Yang mana ketika lahirnya peraturan daerah yang bernuansa syariah ini, melalui dialektika politik yang cukup dramatis [27]. Pertama, bahwa lahirnya perda yang bernuansa syariat ini mustahil terwujud jika hanya dimainkan oleh kelompok Islam kultural tanpa adanya sumbangsih dari beberapa kekuatan politik lain. Kekuatan politik yang dimaksud adalah sokongan dari partai politik dan pihak ekslusif lahirnya.

Lahirnya perda syariat tidak bisa lepas dari peran optimal partai-partai Sekuler lebih khusus partai Golkar. Dan partai partai sekuler lainnya menunjukan paradigma yang cunderung pragmatis pada masa reformasi ini. Ditangan mereka isu syariat menjadi isu yang seksi untuk ditunggangi bagi kepentingan akumulasi kekuatan mereka. peraturan daera syariat ditangan mereka menjadi terpolitisasi.

Kedua, faktor sejarah (romantisme masa lalu) daerah-daerah yang masih perda syariat ini dahulu kala merupakan daerah yang berbasis kelompok perlawanan DI/TII. Pasca lengsernya Soeharto, sebagian yang telah diberangus oleh Orde baru berharsat menemukan kembali identitas diri mereka. Untuk itu, dari mana mereka memulai dan harus dengan kendaraan politik apa mereka menyambungkan identitas diri. Dalam hal ini mereka telah terperangkap oleh nostalgia masa lalu.

Ketiga, kegagalan negara dalam memberikan kesejahteraan dan rasa adil terhadap rakyatnya. Menjamurnya korupsi dan nepotisme di pemerintahan yang membuka jurang pemisah yang cukup signifikan yang berimplikasi pada tingginya angka kemiskinan di masyarakat. Serta kebebasan yang terlalu dalam semua segala hal, maka melahirkan dekandensi moral. akhirnya mereka merasa harus melahirkan perda syariat itu. Hal ini juga merupakan mekanisme yang ditempuh untuk mempertahankan diri [28]. Pertahanan dalam arti satu-satunya cara yang tidak hanya membentengi umat Islam, tetapi sekaligus untuk menyelesaikan berbagai masalah dan penyakit sosial di masyarakat. Pelaksanaan syariat pun diyakini sebagi obat yang paling manjur untuk itu.

Dalam kondisi sosial dan politik seperti ini, sangat bertolak belakang dengan semangat yang selalu diusung oleh Munawir Sjadzali. Karena, yang paling penting menurut Munawir adalah memperjuangkan nilai-nilai Islam, bukan 
memformalisasikannya.

Islam menurut Munawir Sjadzali merupakan sumber inspirasi dan motifasi, Islam sebagai landasan etika dan moral, bukan sebagai sistem sosial dan politik secara keseluruhan, tetapi coba ditangkap spirit dan ruhnya. Oleh sebab itu, yang menjadi dasar pemikiran politik Islam Munawir Sadzali adalah kontekstualisasi teks doktrin guna melakukan aktualisasi ajaran Islam.

Kontekstualisasi ini dilakukan karena telah terjadinya perubahan-perubahan sosial. Inilah yang menjadi spirit reaktualisasi ajaran Islam. Menurut Munawir Reaktualisasi adalah upaya re-interpretasi terhadap doktrin Islam yang memiliki validitasnya sendiri. Ia harus dilakukan, untuk menampung kebutuhan hidup yang terus berkembang [29]. Perspektif yang tidak persama jika dilihat dari sudut pandangan sejarah itu menuntut kemampuan kaum muslim untuk merumuskan ulang nilai-nilai normatif yang langsung dalam konteks relevansinya bagi kebutuhan hidup. Prinsipprinsip teori metodologi hukum (usul al-fiqh) dan kaidah-kaidah hukum agama (qawa'id al-fiqh) akan menjaga agar proses penafsiran kembali itu tidak menyimpang dari prinsip yang terkandung dalam hal yang ingin ditafsirkan ulang statusnya, dan tidak bertentangan dengan maksud dan tujuan status hal itu sendiri semula [30].

Secara tidak disadari, proses reaktualiasasi itu telah menjadi alami dalam kehidupan kaum muslim. Konfigurasi antara nilai-nilai normatif dan reaktualisasi ajaran agama akan tetap menjadi kebutuhan yang nyata, selama kaum muslim tetap pada pendirian untuk tidak "melangkahi" ketentuan sumber tekstual, tetapi juga tidak bersedia menarik diri dari pola kehidupan yang senantiasa berubah. Dengan kata lain, konfigurasi itu merupakan upaya menjaga kontinuitas (persambungan tradisi) di tengah perubahan, agar tidak kehilangan akar-akar budaya dan keagamaan mereka. Dalam jangka panjang, sikap ini akan mematangkan fungsi doktrin Islam dalam hidup mereka.

Doktrin Islam, yang semula berarti kerangka hidup normatif dengan perwujudannya sendiri sebagai doktrin formal, lalu berubah menjadi etika masyarakat yang diserahkan sepenuhnya kepada pilihan-pilihan oleh warga masyarakat. Ia tidak berkembang menjadi hipokritas, karena pada dasarnya kemunafikan haruslah dilihat adanya pada kesengajaan untuk menggelapkan ajaran. Dalam proses reaktualisasi, yang terjadi adalah upaya penafsiran kembali dari satu orang ke lain orang di kalangan kaum muslim, tanpa mengubah pandangan formal masyarakat muslim secara keseluruhan.

Terjadinya proses reaktualiasi, dan konsekuensinya perubahan ketentuan, hal-hal yang telah diterima sebagai konsensus itu menunjukkan vitalitas nilai- nilai normatif Islam. Tidak mudah dilakukan perubahan atasnya, tetapi tetap tidak tertutup kemungkinan bagi perubahan.

Dasar lain yang menjadi landasan pemikiran politik Munawir adalah ijtihad. Pemikiran politik Islam, dalam hal ini, merupakan ijtihad politik dalam rangka menemukan nilai-nilai Islam dalam konteks sistem dan proses politik yang sedang berlangsung [28]. Munawir memandang bahwa semua proses politik dalam sejarah, 


\section{Toharudin}

Nilai-Nilai Keislaman dan Keindonesiaan dalam Membentuk Karakteristik Peradaban Melayu di Indonesia (Studi Pemikiran Munawir Sjadzali)

termasuk suksesi kekuasaan baik yang dilakukan oleh Abu Bakar, Umar, Ustman maupun Ali, sepenuhnya adalah inisiatif dan ijtihad manusia (para sahabat Nabi) belaka. Tak ada pentunjuk dari Nabi, apalagi dari Tuhan, tentang bagaimana seharusnya sebuah tata politik (polity) diciptakan. Dengan kata lain masalah politik sepenuhnya adalah rasional.

Menurut Munawir, ijtihad merupakan wujud kegiatan akal untuk berpikir, yang inherent dengan inti ajaran Islam sendiri (al-Qur'an maupun al-Hadist). Ijtihad bukan lahir dari proses sejarah sebagaimana terjadi di Barat, tetapi lebih manusia kehidupan.

Penggunaan ijtihad tidak terbatas wilayahnya, baik terhadap masalah-masalah yang sudah ada ketentuannya dalam Nas maupun yang tidak ada ketentuannya dalam al-Qur'an dan al-Hadits. Seperti hadis Mu'adz Bin Jabal yang diutus oleh Nabi ke negri Yaman untuk menjadi qadi, menunjukkan perijinan yang luas untuk melakukan ijtihad hukum pada masa Nabi. Dalam pengutusan ini Nabi bersabda:

Artinya: "Bagaimana engkau (mu'az) mengambil suatu keputusan hukum terhadap permasalahan hukum yang diajukan kepadamu? Jawab mu'az saya akan mengambil suatu keputusan hukum berdasarkan kitab Allah SWT(Al-Quran). Kalau kamu tidak menemukan dalam kitab Allah SWT? Jawab Mu'az, saya akan mengambil keputusan berdasarkan keputusan berdasarkan sunnah Raulullah. Tanya Nabi, jika engkau tidak ketemukan dalam sunnah? Jawab Mu'az, saya akan berijtihad, dan saya tidak akan menyimpang. Lalu Rasulullah menepuk dada Mu'az seraya mengatakan segala puji bagi Allah SWT yang telah memberi taufik utusan Rasulnya pada sesuatu yang diridhai oleh Allah SWT dan rasulnya”. (HR. Attirmidzi). [31]

Dalam Hadits ini secara tersirat jelas nabi telah memberikan keluasan dalam mengembangkan akal untuk menetapkan hukum yang belum tersurat dalam AlQuran dan Sunnah. Artinya dengan keluwesannya Nabi dalam melakukan pemecahan masalah-masalah ijtihadiyah telah memberikan legalitas yang kuat terhadap para sahabat.

Lebih lanjut Munawir mendorong tokoh-tokoh intelektual sesama muslim untuk melakukan ijtihad secara jujur, untuk menjadikan Islam lebih tanggap terhadap berbagai kebutuhan situasi lokal dan temporal Indonesia. Menurut Munawir, dalam perkembangan sejarah doktrin Islam terdapat banyak penguasa Islam yang berani menempuh kebijakan hukum yang tidak sesuai secara harfiyah dengan bunyi ayatayat al-Qur'an dan atau ucapan maupun tindakan Nabi Muhammad SAW. Maka kalau kita berusaha memahami ajaran Islam dengan akal budi, dan tentu saja dengan rasa penuh tanggungjawab kepada Islam, kita bukanlah yang pertama dalam berijtihad [32].

Diilhami oleh keberanian dan kejujuran Umar, Munawir menyatakan bahwa harus dilakukan langkah-langkah yang berani dan jujur dalam memberlakukan ajaran-ajaran Islam. Seraya meyakini dinamisme dan vitalitas doktrin Islam, ia mengusulkan agar kaum muslim melaksanakan agenda-agenda reaktualisasi lewat ijtihad, untuk menjadikan Islam lebih sesuai dengan kekhasan lokal dan temporal Indonesia. Formalisasi Islam menjadi RUU atau perda-perda akan menghilangkan kekhasan Indonesia yang merupakan negara binneka tunggal ika, dan rentan 
menimbulkan konflik.

Munawir Sjadzali berpendapat bahwa Islam adalah sebuah sistem kehidupan yang menurut penganutnya untuk aktif mewujudkan dalam kehidupan umat Islam di dunia nyata. Termasuk dalam kehidupan berbangsa dan bernegara. Islam menurut Munawir Sjadzali merupakan sumber inspirasi dan motivasi, landasan etika dan moral, bukan sebagai sistem sosial dan politik secara keseluruhan, tetapi harus ditangkap spirit dan ruhnya. Oleh sebab itu, yang menjadi dasar pemikiran politik Islam Munawir Sadzali adalah kontekstualisasi teks doktrin guna melakukan aktualisasi ajaran Islam. Dalam wujud Pancasila ajaran Islam di dunia empiris terlihat dari tegaknya keadilan, kemerdekaan, dan kesejahteraan umat. Munawir Sjadzali, menjelasakan ketika mayoritas karakter masyarakat kuat, positif, tangguh maka peradaban yang tinggi dapat di bangun dengan baik dan sukses, sebaliknya jika mayoritas karakter masyarakat memiliki karakter negatif dan lemah mengakibatkan peradaban yang dibangun menjadi lemah, sebab peradaban tersebut dibangun dalam fondasi yang amat lemah.

Munawir Sjadzali menjelaskan dalam membangun peradaban di Indonesia strategi yang harus dilakukan adalah mereaktualisasikan sumber ajaran Islam di dalam nilai-nilai keindonesiaan, sebagai karakter bangsa Indonesia secara konseptual dengan menggunakan pilar moral (Pancasila). Karakter individual maupun komunal dibangun melalui dua aspek yang saling terkait yaitu aspek otonomi dan aspek heteronomi. Otonomi merupakan usaha dalam proses pendidikan yang diimplementasikan melalui pengajaran, pembiasaan, peneladanan, motivasi, dan penegak aturan. Sementara, aspek heteromoni merupakan usaha yang dilakukan oleh lingkungan (luar pendidikan) yakni adanya keadilan sosial ekomomi, penegakan hukum tanpa timbang pilih, keteladanan pimpinan, serta keteraturan norma-norma sosial. Melalui Pancasila yang secara subtantif adalah nilai-nilai ajaran Islam, bangsa Indonesia membangun ilmu-ilmu baru. Di atas ilmu-ilmu baru itu dibagun sistem kemasyarakatan baru. Dengan sistem kemasyarakatan baru itu umat Islam menata masyarakata baru. Dengan masyarakat baru yang tertata secara Islami itulah umat Islam membangun sebuah peradaban Islam tanpa nama Islam secara formal. Dengan bangunan perabadan Islam itulah umat Islam dapat bersaing dan mengungguli peradaban dunia lainnya, secara cerdas dan bermartabat.

Munawir Sjadzali adalah modernis muslim yang menegaskan bahwa Islam dan Pancasila tidak bertentangan, merupakan dua hal yang berkaitan satu dengan lainya, Islam adalah sumber nilai norma dan moral, sedangkan Pancasila merupakan wadah untuk menjalankannya nilai-nilai keislam dalam keseharian di Indonesia. Pancasila adalah subtansi ajaran Islam itu sendiri. Munawir Sjadzali berpendapat bahwa dengan Pancasila umat Islam dapat membangun sebuah peradaban Islam yang universal secara legal di Indonesia. Munawir Sjadzali berpendapat bahwa Islam adalah sebuah sistem kehidupan yang menurut penganutnya untuk aktif mewujudkan dalam kehidupan umat Islam di dunia nyata. Termasuk dalam kehidupan berbangsa dan bernegara. Untuk itu dibutuhkan kekuasaan politik untuk mewujudkannya. Tetapi kekuasaan politik itu tidak dimaksudkan untuk mewujudkan sisi simbol formal Islam secara legal seperti negara Islam. Tetapi yang diperjuangkan untuk diterapkan adalah sisi nilai-nilai Islam itu atau 


\section{Toharudin}

Nilai-Nilai Keislaman dan Keindonesiaan dalam Membentuk Karakteristik Peradaban Melayu

di Indonesia (Studi Pemikiran Munawir Sjadzali)

subtansinya. Pancasila adalah ideologi negara yang bersumber pada subtansi ajaran Islam yang telah menjadi jiwa umat Islam Indonesia sejak lama. Karena itu perjuangan untuk mewujudkan sebuah negara dan peradaban yang Islami dapat dilakukan melalui Pancasila yang merupakan patokan bersama cara berpikir, cara menilai, dan cara berperilaku seluruh bangsa Indonesia.

\section{Kesimpulan}

Dalam penelitian ini, dapat disimpulkan bahwa: Pertama, Islam menurut Munawir Sjadzali adalah sebuah sistem kehidupan yang menurut penganutnya untuk aktif mewujudkan dalam kehidupan umat Islam di dunia nyata. Termasuk dalam kehidupan berbangsa dan bernegara sebagai sumber inspirasi dan motivasi, landasan etika dan moral dalam membangun peradaban di Indonesia. Kedua, strategi yang ditawarkan Munawir Sjadzali dalam membangun peradaban di Indonesia yaitu dengan mereaktualisasikan nilai keislaman dan keindonesiaan, yaitu nilai berketuhanan, nilai kemanusiaan yang adil dan beradab, nilai persatuan dan kesatuan, nilai kebijaksanaan dalam kepemimpinan, dan nilai keadilan. Kelima nilai tersebut dikenal dengan mana Pancasila. Ketiga, Pancasila yang secara subtantif adalah nilai-nilai ajaran Islam, umat Islam Indonesia membangun ilmu baru, sistem dan tatanan kemasyarakatan baru yang tertata secara Islami itulah bangsa Indonesia membangun sebuah peradaban Islam tanpa nama Islam secara formal, serta dapat bersaing dan mengungguli peradaban dunia lainnya, secara cerdas dan bermartabat. 


\section{Daftar Pustaka}

[1] M. Mulia, Negara Islam, Depok: Katakita, 2010.

[2] M. Azhar, Filsafat Politik Perbandingan Antara Islam dan Barat, Jakarta: Rajawali Pers, 1997.

[3] Surwandono, Pemikiran Politik Islam, Yogyakarta: LPPI UMY, 2001.

[4] M. Jameelah, Islam dan Modernisme, Surabaya: Usahana Nasional, 2010.

[5] A. Hamid and Yahya, Pemikiran Modern Dalam Islam, Bandung: Pustaka Setia, 2010.

[6] S. Maryam, Sejarah Peradaban Islam Dari Masa Klasik Hingga Modern, Yogyakarta: Jurusan SPI Fakultas Adab IAIN Sunan Kalijaga LESFI, 2003.

[7] A. Suhelmi, Polemik Negara Islam Soekarno V.S Mohammad Natsir, Jakarta: Terajut, 2002.

[8] M. Natsir, Islam Sebagai Dasar Negara, Bandung: Rega Asry, 2004.

[9] S. Ma'arif, Islam dan Masalah Kenegaraan, Jakarta: LP3ES, 1987.

[10] A. Gani, Islam Datang Ke Nusantara Membawa Tamadun (Kecerdasan), Bandung: Alma'arif, 1963.

[11] I. Syaputra, A. Kundandar and F. Ikbal, "Agama, Politik, dan Ideologi (Analisis Wacana Kritis Berita Korupsi Petinggi Partai Politik," El-Helkam Jurnal Studi Keislaman, vol. 1, no. 1, 2016.

[12] T. Nugroho, Pengantar Kepada Pemikiran Hidayat Nataatmadja, Yogyakarta: Lanskap, 2010.

[13] M. P. Ketawang, Menjawab Persoalan Bangsa Menuju Masa Depan Cemerlang, Jakarta: LPPM DIKTIS dan Kementerian Agama RI, 2013.

[14] S. Zuhri, Sejarah Kebangkitan Islam dan Perkembangannya di Indonesia, Bandung: Al-Maari'f, 1981.

[15] Kuntowijoyo, Islam Sebagai Ilmu, Metodologi, dan Etika, Jakarta: Terajut, 2004.

[16] I. Pautanu and T. Rosyadi, Nilai-Nilai Keislaman Untuk Membangun Karakter Bangsa, Jakarta: UIN Syarif Hidayatullah, 2015.

[17] D. Kusuma, "Kompas," Kompas Cyber Media, 2009. [Online].

[18] M. Sjadzali, Bunga Rampai Wawasan Islam Dewasa Ini, Jakarta: Universitas Indonesia Press., 1994.

[19] A. Hasanah, Pendidikan Berbasis Karakter, Jakarta: Media Indonesia, 2009.

[20] M. Sjadzali, Islam dan Tata Negara: ajaran, sejarah dan pemikiran, Jakarta: UI Press, 1991.

[21] T. Rosyadi, Nilai-Nilai Keindonesiaa Dalam Membentuk Karakter Peradaban Bangsa, Jakarta: UIN Syarif Hidayatullah, 2015.

[22] N. Madjid, Islam Kemoderenan dan Keindonesiaan, Bandung: Mizan, 1999.

[23] N. Madjid, Mencari Akar-Akar Islam Bagi Pluralisme Modern, Pengalaman Indonesia, M. R. Woodward, Ed., Bandung: Mizan, 1998.

[24] N. Madjid, Masyarakat Religius, Jakarta: Paramadina, 2000.

[25] M. Sjadzali., Indonesia's Muslim Parties and Their Political Concepts, Thesis untuk Master of Arts, Graduate School, Washinton DC: George Town University, 1957. 


\section{Toharudin}

Nilai-Nilai Keislaman dan Keindonesiaan dalam Membentuk Karakteristik Peradaban Melayu

di Indonesia (Studi Pemikiran Munawir Sjadzali)

[26] M. S. Anwar, Pemikiran dan Aksi Islam Indonesia, Jakarta: Paramadina, 2012.

[27] M. Sjadzali, Aspirasi Umat Islam Terpenuhi Tanpa Partai Islam, Jakarta: Departemen Agama, 1992.

[28] A. Komarudin, Dasar-Dasar Manajemen Inventasi dan Portofolio Dalam Pandangan Munawir Sjadzali Era Kemerdekaan, Jakarta: PT. Asdi Mahasatya, 2001.

[29] M. Sjadzali, Bunga Rampai Perkembangan Bangsa, Yogyakarta: Pustaka Pelajar, 1993.

[30] K. Hidayat and A. G. AF, Pengantar Editor dalam Islam, Negara dan Civil Society, Jakarta: Paramadina, 2005.

[31] M. Sjadzali, Islam Realitas Baru dan Orientasi Masa Depan Bangsa, Jakarta: UI, 1997.

[32] M. Q. Zaman, "The Caliph, The Ulama, and The law: Defining the Role and Function of the Caliph in the Early "Abbasidh Period," Islamic Law and Society, vol. 4, 1997. 